\title{
The vasodilatory effects of medicinal herbs on the cardiovascular system: A systematic review
}

\author{
Nasrollah Moradifar ${ }^{1}$, Ali Asghar Kiani $^{(\mathbb{D}}$, Navid Bakhtiari $^{{ }^{\circledR}}$, Morteza Amraei $^{4^{\circledR}}$, Arash Amin $^{1^{*}}$ \\ ${ }^{1}$ Cardiovascular Research Center, Lorestan University of Medical Sciences, Khorramabad, Iran \\ ${ }^{2}$ Razi Herbal Medicines Research Center, Lorestan University of Medical Sciences, Khorramabad, Iran \\ ${ }^{3}$ Faculty of Pharmacy, Ayatollah Amoli Branch, Islamic Azad University, Amol, Iran \\ ${ }^{4}$ Department of Health Information Technology, School of Paramedical Sciences, Lorestan University of Medical Sciences, Lorestan, Khorramabad, \\ Iran
}

\section{A R T I C L E I N F O}

Article Type:

Review

\section{Article History:}

Received: 2 June 2021

Accepted: 12 August 2021

\section{Keywords:}

Vasodilation

Vasorelaxant

Medicinal plant

Hypertension

Extract

Essential oil

\begin{abstract}
A B S T RA C T
Vasodilators are drugs that induce or start the widening of blood vessels and are commonly applied to treat disorders with irregularly high blood pressure, including hypertension, congestive heart failure, and angina. The present study aims to systematically review the studies on the vasodilation effects of medicinal herbs. The study was done according to the 06- Preferred Reporting Items for Systematic reviews and Meta-Analyses (PRISMA) guidelines and registered in the CAMARADES-NC3Rs Preclinical Systematic Review and Meta-Analysis Facility (SyRF) database. Various English databases, such as Scopus, PubMed, Web of Science, EMBASE, and Google Scholar, were used to find publications about the vasodilation effects of medicinal herbs with no date limitation. The searched terms and keywords were: "medicinal herbs", "medicinal plants", "vasodilator", "vasorelaxant", "hypertension", "high blood pressure", "vasodilation", "extract", "essential oil". Out of 1820 papers (up to 2020), 31 papers meeting the inclusion criteria were reviewed. The most important medicinal plants with vasodilation/vasorelaxant activity belonged to the family Asteraceae (19.4\%) followed by Zingiberaceae (9.7\%). Aerial parts (30.5\%), leaves (30.5\%), followed by roots (11.1\%) were the most common parts used in the studies. Ethanolic (33.3\%), aqueous (22.2\%), methanolic (19.4\%), and hydroalcoholic (8.3\%) methods were the most frequently used extracting methods. Herbal essential oils (13.9\%) have also been commonly used. The results of the current review study revealed that the plant vasodilatory agents were might be used as an alternative and complementary source to treat hypertension as they had lower important toxicity. Nevertheless, more investigations, particularly clinical trials, are needed to clear this suggestion.
\end{abstract}

Implication for health policy/practice/research/medical education:

This review presents a detailed insight into the effective medicinal herbs on vasodilation and presents a list of medicinal plants for the treatment of hypertension, congestive heart failure, and angina, which might be used to prepare new agents.

Please cite this paper as: Moradifar N, Kiani AA, Bakhtiari N, Amraei M, Amin A. The vasodilatory effects of medicinal herbs on the cardiovascular system: A systematic review. J Herbmed Pharmacol. 2021;10(4):367-374. doi: 10.34172/jhp.2021.43.

\section{Introduction}

Vasodilatation is well-known as one of the main therapeutic strategies to treat some cardiovascular diseases with high blood pressure $(1,2)$. Vasodilators are drugs that induce or start the widening of blood vessels, which are commonly applied to treat disorders with irregularly high blood pressure, including hypertension, congestive heart failure, and angina (3-5).

At present, there are many agents that have been shown to have vasodilation effects by various mechanisms, such as inhibiting angiotensin-converting enzyme (ACE), blocking calcium channels, opening potassium channel, or inhibiting cGMP-specific 3',5'-cyclic phosphodiesterase (PDE5) (6,7). However, despite the potential effects of the existing vasodilators, recent studies have indicated some limitations of these drugs, including drug resistance, drug dependence, reducing the systemic vascular resistance through renal retention of sodium and water, orthostatic

*Corresponding author: Arash Amin, MD,

Email: a.amin@lums.ac.ir 
hypotension and syncope upon standing, increasing the heart rate and inotropy $(8,9)$. Therefore, the development and discovery of novel agents as blood vessel dilators are promising among researchers.

Medicinal plants have always been used by humans throughout history. The use of plants, plant materials, plant compounds has been introduced as herbal medicine all over the world $(10,11)$. On the other hand, the return to nature and the reuse of drugs of plant and natural origin takes place in a situation where today's man has faced the side effects of these drugs. Scientific research has proven the effectiveness and safety of some complementary medicine methods, including herbs, in the treatment of some diseases $(12,13)$. The present study aims to systematically review the studies on the vasodilation effects of some medicinal herbs.

\section{Methods}

Search strategy

This study was done according to the Preferred Reporting Items for Systematic reviews and MetaAnalyses (PRISMA) guidelines (14) and registered in the CAMARADES-NC3Rs Preclinical SyRF database. Various English databases, such as Scopus, PubMed, Web of Science, EMBASE, and Google Scholar, were used to find publications about the vasodilation effects of medicinal herbs up to 2020. The searched words and terms were: "medicinal herbs", "medicinal plants", "vasodilator", "vasorelaxant", "hypertension", "high blood pressure", "vasodilation", “extract”, “essential oil” (Figure 1).

Quality assessment and article selection

Initially, the publications were imported to the EndNote X9 software based on the Systematic Review Centre for Laboratory Animal Experimentation (SYRCLE); whereas the duplicate papers were omitted. Then, three independent authors tested the titles and abstracts of the papers, and the relevant publications were included for further analysis. The same authors carefully analyzed the publications, and the suitable papers with acceptable inclusion criteria were selected. Any disagreement between the authors were resolved through the corresponding author

Inclusion and exclusion criteria

All papers evaluating the vasodilation effects of medicinal plants were included, whereas the studies with only abstract, inadequate information, failure to match methods with results, and inappropriate interpretation of the results were excluded (Figure 1).

\section{Data extraction}

The independent researchers extracted data, including the name of plant, plant family, the part used, type of extraction, concentration, and important results.

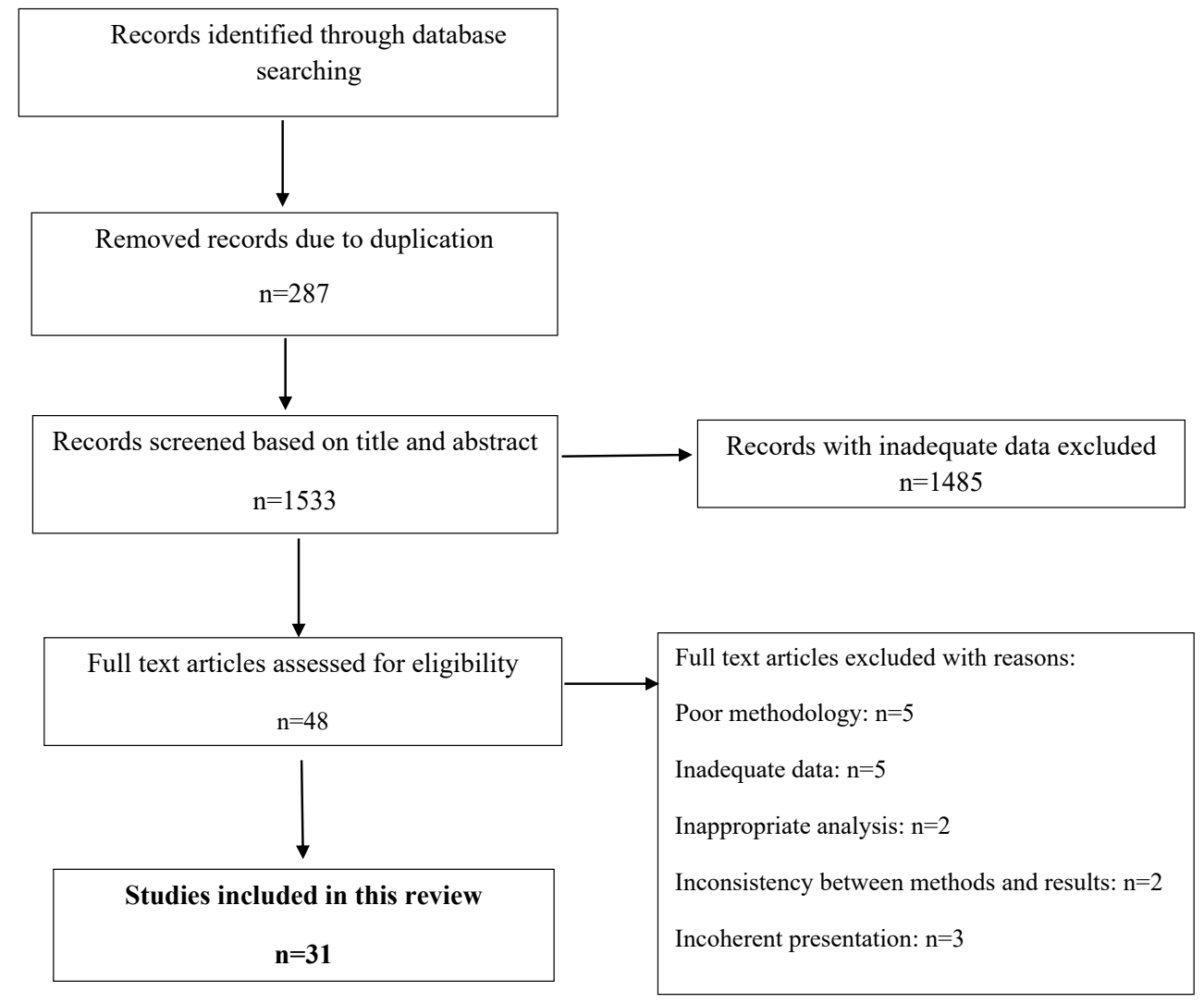

Figure 1. Flowchart describing the study design process. 


\section{Results}

Out of 1820 papers, 48 papers were assessed for eligibility. While 17 papers (9 in vivo and 8 in vitro studies) were excluded from the study, 31 papers, which met the inclusion criteria were selected for discussion. Thirty-one plant species belonging to 33 genera and 27 families had vasodilation/vasorelaxant activity (Table 1) with various mechanisms (Figure 2). Among 31 selected papers, 16 papers (51.6\%) were evaluated the vasodilation/ vasorelaxant activity of medicinal herbs in vivo, whereas 15 papers (48.4\%) were assessed the vasodilation/vasorelaxant activity of medicinal herbs in vitro. The most widely used medicinal plants with vasodilation/vasorelaxant activity belonged to the family Asteraceae (19.4\%) followed by Zingiberaceae (9.7\%). Aerial parts (85.8\%) such as leaves $(30.5 \%)$, followed by ground parts (14.2\%) such as root (11.1\%) were the most common parts used in the studies. The findings of the present review showed that ethanolic extract (33.3\%), followed by aqueous extract $(22.2 \%)$ and methanolic extract (19.4\%) were considered as the desired approaches of herbal extraction, whereas the essential oil $(13.9 \%)$ and hydroalcoholic extract $(8.3 \%)$ were the second most used herbal extractions.

\section{Discussion}

According to the WHO reports, herbal medicines and their derivatives because of low or no industrial handling and toxicity have been extensively used to treat various diseases such as diabetes, cancer, cardiovascular, and gastrointestinal problems, by local or regional healing methods in developed and developing countries $(10,11)$. Reviews have previously demonstrated that the biological activities and treating properties of medicinal plants are due to the secondary metabolites existing in plants making them a reliable source for providing of new agents $(12,13)$.

Flavonoids are considered one of the key secondary metabolites of plants, which have numerous pharmacological and therapeutics properties in the cardiovascular system, including vasodilation, antiatherogenic, antihypertensive, antioxidant, and antiplatelet properties $(46,47)$. These compounds show their vasodilation and antihypertensive effects through inhibiting tyrosine kinase Pyk2 as the main enzyme to regulate calcium channels, activation of the $\mathrm{cAMP} /$ protein kinase A cascade, modulating the renin-angiotensinaldosterone system, adapting the contraction of vessels of smooth muscles, activating the potassium channels, and decreasing calcium ions in cells by delaying voltage-gated calcium channels, etc (48).

Other important compounds in plants, which have exhibited considerable vasodilation and antihypertensive effects, are phenolic compounds $(49,50)$. Studies have reported that polyphenols display their effects through some mechanisms such as increasing endotheliumderived nitric oxide bioactivity, suppression of smooth muscle activation, regulating calcium channels, etc $(51,52)$.

Terpenes are well-known as the key herbal compounds with a broad spectrum of pharmacological and therapeutic activities, including antihypertensive and vasodilation properties (53). Reviews demonstrated that these secondary metabolites act through a direct effect on vascular smooth muscle, an effect on the peripheral vascular resistance, no release of $\mathrm{NO}$, activating the NOcGMP pathway, and inhibition of $\mathrm{Ca}^{2+}$ influx, etc (54).

The present review showed that aerial parts, especially the leaves, were the most common parts of medicinal plants used for their vasodilatory activities. Reviews have demonstrated that leaves are well-known as the favored part of plants for therapeutics aims due to having a high percentage of bioactive composites; and convenience in harvesting without any damage to the herb (55-58).

We found that ethanolic extract, aqueous extract, and methanolic extract were the most used plant formulations. A previous study revealed that the general use of these extracts represents the role of solvents in the extraction of potential bioactive components from different plants and various parts of these herbs (59). The adverse side effects of herbal medicines are linked to a number of factors, including the toxicity of main constituents, lack of suitable manufacturing techniques, and consequently, heavy metals or microbes contaminations, and side effects on consumers, which are dependent on age, genetic and the underlying diseases of them (60-62). Today, exposure of a plant extracts in humans can be evaluated by detecting the increasing effects and doses that cause toxicity, such as carcinogenic, mutagenic, and teratogenic problems (63). A number of toxicity tests are necessary to assess the level of damages triggered by herbal extracts and their derivatives (63). In all in vivo studies, including in the present review, the used doses of medicinal herbs for evaluation of their vasodilation/vasorelaxation activities were based on the reliable toxicity tests such as acute toxicity, sub-chronic toxicity, the fixed-dose procedure indicating that these medicinal herbs in used doses have no significant toxicity in tested animals.

\section{Limitations}

The main limitations of the present study are the lack of phytochemical analysis on most plants to identify the main components of the plant, the lack of basic vasodilation mechanisms of some plants, and the lack of clinical studies.

\section{Conclusion}

Recently, numerous studies have been carried out on the antihypertensive and vasodilation effects of herbal extracts and essential oils alone or in combination with existing drugs. The results revealed that the herbal vasodilatory agents might be used as an alternative and complementary 
Table 1. List of included papers related to the vasodilation effects of medicinal herbs

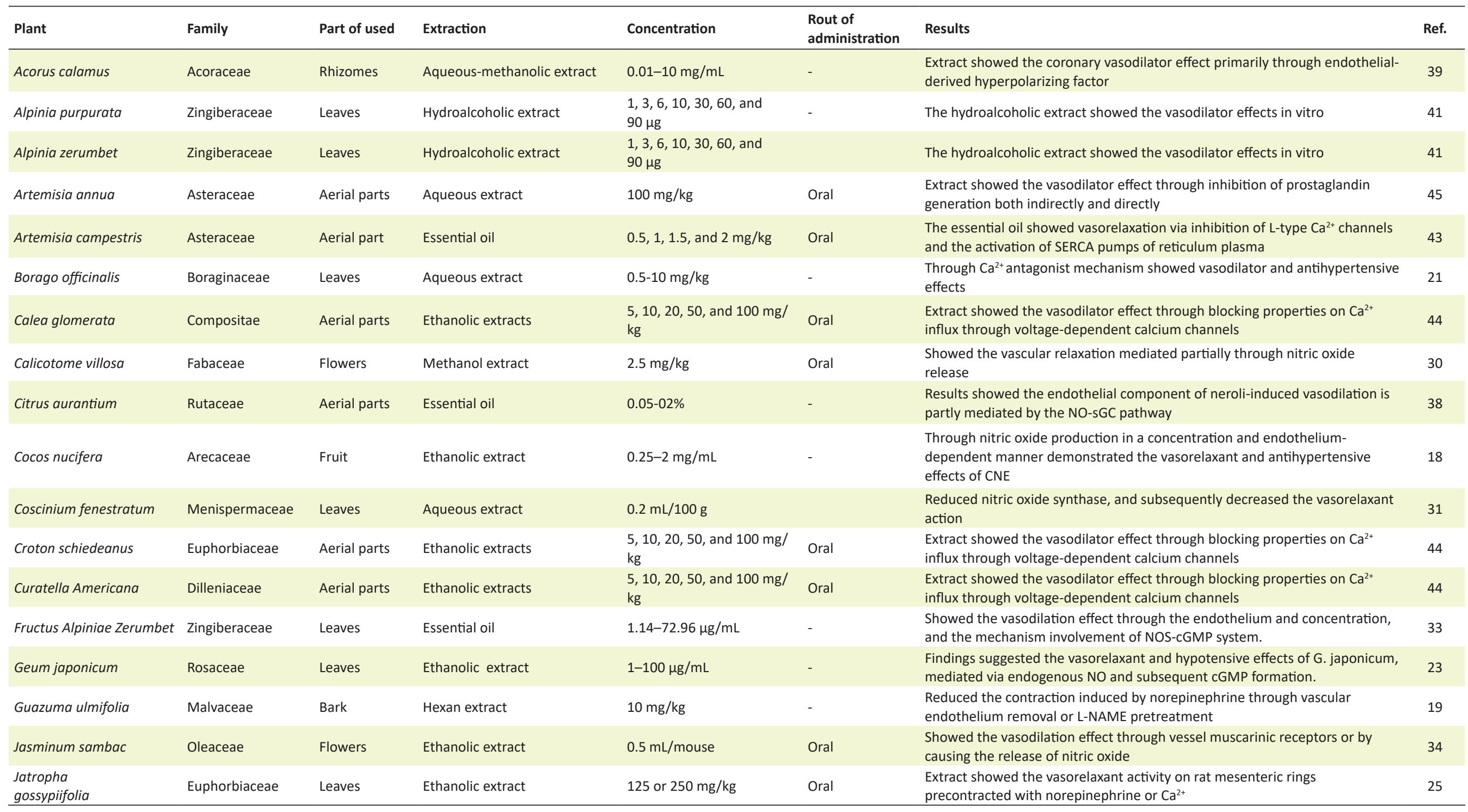




\begin{tabular}{|c|c|c|c|c|c|c|c|}
\hline Plant & Family & Part of used & Extraction & Concentration & $\begin{array}{l}\text { Rout of } \\
\text { administration }\end{array}$ & Results & Ref. \\
\hline Laelia anceps & Orchidaceae & Root & Methanolic extract & 100 mg/kg & Oral & $\begin{array}{l}\text { Induced vasorelaxant and antihypertensive effects by blockade of } \mathrm{Ca}^{2+} \\
\text { channels }\end{array}$ & 17 \\
\hline Laelia autumnalis & Orchidaceae & Root & Methanolic extract & $\begin{array}{l}15,46,150,300 \text {, and } 1500 \\
\mu \mathrm{g} / \mathrm{mL}\end{array}$ & - & $\begin{array}{l}\text { Induced relaxation in rat aortic rings through an endothelium-independent } \\
\text { pathway, involving blockade of } \mathrm{Ca}^{2+} \text { channels and a possible cGMP enhanced } \\
\text { concentrations and also caused an antihypertensive effect }\end{array}$ & 15 \\
\hline Lippia alba & Verbenaceae & Aerial parts & Ethanolic extracts & $\begin{array}{l}5,10,20,50 \text {, and } 100 \mathrm{mg} / \\
\mathrm{kg}\end{array}$ & Oral & $\begin{array}{l}\text { Extract showed the vasodilator effect through blocking properties on } \mathrm{Ca}^{2+} \\
\text { influx through voltage-dependent calcium channels }\end{array}$ & 44 \\
\hline $\begin{array}{l}\text { Loranthus } \\
\text { ferrugineus }\end{array}$ & Loranthaceae & Leaves & Methanol extract & $0.01 \mu \mathrm{M}$ & - & $\begin{array}{l}\text { Demonstrated its vascular effect by reversible noncompetitive antagonism of } \\
\text { norepinephrine-induced vasoconstriction }\end{array}$ & 22 \\
\hline Lupinus amandus & Fabaceae & Aerial parts & Ethanolic extracts & $\begin{array}{l}5,10,20,50 \text {, and } 100 \mathrm{mg} / \\
\mathrm{kg}\end{array}$ & Oral & $\begin{array}{l}\text { Extract showed the vasodilator effect through blocking properties on } \mathrm{Ca}^{2+} \\
\text { influx through voltage-dependent calcium channels }\end{array}$ & 44 \\
\hline Mammea atricana & Calophyllaceae & Stem bark & $\begin{array}{l}\text { Methanol /methylene chloride } \\
\text { extract }\end{array}$ & 200 mg/(kg) & Oral & $\begin{array}{l}\text { Had a beneficial effect in patients with NO deficiency by improving their } \\
\text { endothelium-dependent vasorelaxation }\end{array}$ & 29 \\
\hline Myrtus communis & Myrtaceae & Aerial parts & Methanol extract & $0.01-5 \mathrm{mg} / \mathrm{ml}$ & - & $\begin{array}{l}\text { Revealed the vasodilator effects through a possible calcium channel blocking } \\
\text { activity }\end{array}$ & 37 \\
\hline Nigella sativa & Ranunculaceae & Seed & Essential Oil & $10-100 \mu \mathrm{g} / \mathrm{mL}$ & - & $\begin{array}{l}\text { Essential oil showed the vasodilatory effects through blockade of both } \\
\text { voltage-sensitive and receptor-operated calcium channels }\end{array}$ & 40 \\
\hline $\begin{array}{l}\text { Passiflora Edulis } \\
\text { rind }\end{array}$ & Passifloraceae & Leaves & Methanol extract & 10 and $50 \mathrm{mg} / \mathrm{kg}$ & Oral & $\begin{array}{l}\text { The antihypertensive effect of the extract in SHRs might be due mostly to the } \\
\text { GABA-induced antihypertensive effect and partially to the vasodilatory effect } \\
\text { of polyphenols including luteolin }\end{array}$ & 27 \\
\hline Pectis brevipedunculata & Asteraceae & Aerial parts & Essential oil & $1-10 \mathrm{mM}$ & - & $\begin{array}{l}\text { Showed the vasorelaxation of thoracic aorta by affecting the NO/cyclic GMP } \\
\text { pathway and reduced the calcium influx by the blockade of voltage- } \\
\text { dependent } \mathrm{L} \text {-type } \mathrm{Ca}^{2+} \text { channels }\end{array}$ & 36 \\
\hline Raphanus sativus & Brassicaceae & Seed & Aqueous extract & $0.03-3.0 \mathrm{mg} / \mathrm{mL}$ & Oral & $\begin{array}{l}\text { Showed the antihypertensive and vasodilation effects mediated through } \\
\text { activation of muscarinic receptors }\end{array}$ & 32 \\
\hline Saururus chinensis & Saururaceae & Root & Ethanolic extract & 10,30 , and $100 \mathrm{mg} / \mathrm{kg}$ & Oral & $\begin{array}{l}\text { Showed the antihypertensive effect through its direct vasorelaxant properties } \\
\text { and negative inotropic actions }\end{array}$ & 28 \\
\hline Sclerocarya birrea & Anacardiaceae & Stem-bark & Ethanolic extract & 60,120 , and $240 \mathrm{mg} / \mathrm{kg}$ & Oral & Extract had reno- and cardio-protective effects in diabetes mellitus & 24 \\
\hline Senecio nutans & Asteraceae & $\begin{array}{l}\text { Branches, } \\
\text { leaves }\end{array}$ & Hydroalcoholic extract & $1-4 \mu \mathrm{g} / \mathrm{mL}$ & - & $\begin{array}{l}\text { Extract showed the vasodilator effect through endothelium-dependent (NO) } \\
\text { and or independent, and may involve a modulation of the calcium channels. }\end{array}$ & 42 \\
\hline Tanacetum vulgare & Asteraceae & Leaves & Aqueous extract & $800 \mu \mathrm{g} / \mathrm{mL}$ & & $\begin{array}{l}\text { The aqueous extract of Tanacetum possesses NO-mediated and NO- } \\
\text { independent vasorelaxing properties in vitro }\end{array}$ & 20 \\
\hline Tribulus terrestris & Zygophyllaceae & Fruits & Aqueous extract & $\begin{array}{l}\text { A single daily dose of } 10 \\
\mathrm{mg} / \mathrm{kg}\end{array}$ & Oral & $\begin{array}{l}\text { Significantly reduced the systolic blood pressure; whereas reduced the ACE } \\
\text { activity significantly lower than that of hypertensive rats }\end{array}$ & 16 \\
\hline
\end{tabular}




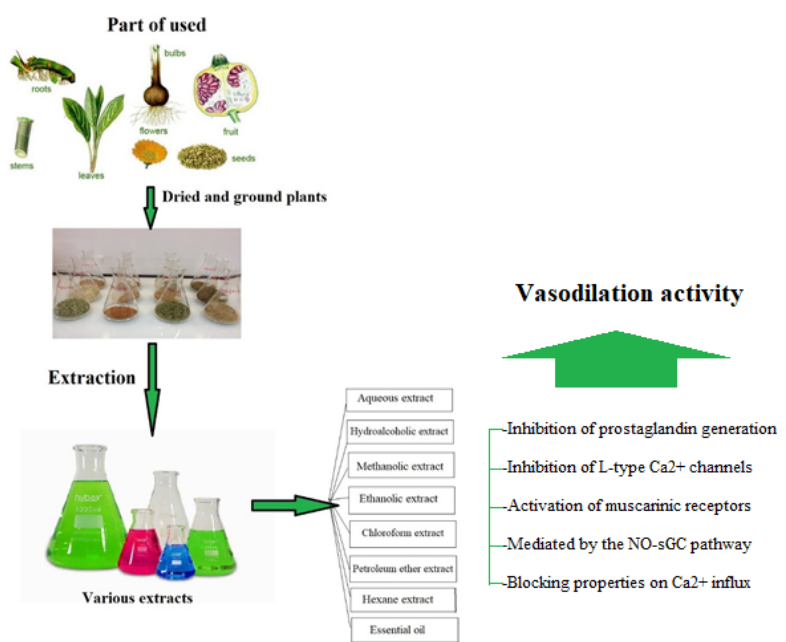

Figure 2. Schematic figure medicinal herbs and their extracts used for vasodilation activity.

source to treat hypertension as had lower important toxicities. Nevertheless, more investigations, especially clinical trials, are needed to clear this suggestion.

\section{Authors' contributions}

AA, AK, NB, MA and NM reviewed and contributed to data collection and preparation of the manuscript. The first draft was prepared by AA, and NM. All authors read the final version and confirmed it for publication.

\section{Conflict of interests}

The authors declared no competing interests.

\section{Ethical considerations}

Ethical issues (including plagiarism, data fabrication, double publication and etc.) have been completely observed by the authors.

\section{Funding/Support}

This study received no funding or grant.

\section{References}

1. Lind L, Granstam SO, Millgård J. Endothelium-dependent vasodilation in hypertension: a review. Blood Press. 2000;9(1):4-15.

2. Møller S, Bendtsen F. The pathophysiology of arterial vasodilatation and hyperdynamic circulation in cirrhosis. Liver Int. 2018;38(4):570-80. doi: 10.1111/liv.13589.

3. Lind L. Lipids and endothelium-dependent vasodilation--a review. Lipids. 2002;37(1):1-15. doi: 10.1007/s11745-0020858-6.

4. Tang F, Yan HL, Wang LX, Xu JF, Peng C, Ao H, et al. Review of natural resources with vasodilation: traditional medicinal plants, natural products, and their mechanism and clinical efficacy. Front Pharmacol. 2021;12:627458. doi: 10.3389/fphar.2021.627458.

5. Swenson ER. New insights into carbonic anhydrase inhibition, vasodilation, and treatment of hypertensive- related diseases. Curr Hypertens Rep. 2014;16(9):467. doi: 10.1007/s11906-014-0467-3.

6. Kincaid-Smith P. Vasodilators in the treatment of hypertension. Med J Aust. 1975;1(SP2):7-9. doi: 10.5694/ j.1326-5377.1975.tb140363.x.

7. Osterziel KJ, Julius S. Vasodilators in the treatment of hypertension. Compr Ther. 1982;8(11):43-52.

8. Pettinger WA, Mitchell HC. Side effects of vasodilator therapy. Hypertension. 1988;11(3 Pt 2):II34-6. doi: 10.1161/01.hyp.11.3_pt_2.ii34.

9. Cohn JN, Archibald DG, Ziesche S, Franciosa JA, Harston WE, Tristani FE, et al. Effect of vasodilator therapy on mortality in chronic congestive heart failure. Results of a Veterans Administration Cooperative Study. N Engl J Med. 1986;314(24):1547-52. doi: 10.1056/ nejm 198606123142404 .

10. Petrovska BB. Historical review of medicinal plants' usage. Pharmacogn Rev. 2012;6(11):1-5. doi: 10.4103/09737847.95849.

11. Ahmad Dar A, Shahnawaz M, Qazi PH. General overview of medicinal plants: a review. J Phytopharmacol. 2017;6(6):349-51.

12. Silva NC, Fernandes Júnior AJ. Biological properties of medicinal plants: a review of their antimicrobial activity. J Venom Anim Toxins Incl Trop Dis. 2010;16(3):402-13. doi: 10.1590/s1678-91992010000300006.

13. Rouhi-Boroujeni $\mathrm{H}$, Heidarian E, Rouhi-Boroujeni $\mathrm{H}$, Deris F, Rafieian-Kopaei M. Medicinal plants with multiple effects on cardiovascular diseases: a systematic review. Curr Pharm Des. 2017;23(7):999-1015. doi: 10.2174/1381612822 666161021160524.

14. Moher D, Liberati A, Tetzlaff J, Altman DG. Preferred reporting items for systematic reviews and meta-analyses: the PRISMA statement. PLoS Med. 2009;6(7):e1000097. doi: 10.1371/journal.pmed.1000097.

15. Vergara-Galicia J, Ortiz-Andrade R, Castillo-España $P$, Ibarra-Barajas M, Gallardo-Ortiz I, Villalobos-Molina R, et al. Antihypertensive and vasorelaxant activities of Laelia autumnalis are mainly through calcium channel blockade. Vascul Pharmacol. 2008;49(1):26-31. doi: 10.1016/j. vph.2008.04.002.

16. Sharifi AM, Darabi R, Akbarloo N. Study of antihypertensive mechanism of Tribulus terrestris in 2K1C hypertensive rats: role of tissue ACE activity. Life Sci. 2003;73(23):2963-71. doi: 10.1016/j.lfs.2003.04.002.

17. Vergara-Galicia J, Ortiz-Andrade R, Rivera-Leyva J, Castillo-España P, Villalobos-Molina R, Ibarra-Barajas M, et al. Vasorelaxant and antihypertensive effects of methanolic extract from roots of Laelia anceps are mediated by calciumchannel antagonism. Fitoterapia. 2010;81(5):350-7. doi: 10.1016/j.fitote.2009.10.009.

18. Bankar GR, Nayak PG, Bansal P, Paul P, Pai KS, Singla RK, et al. Vasorelaxant and antihypertensive effect of Cocos nucifera Linn. endocarp on isolated rat thoracic aorta and DOCA salt-induced hypertensive rats. J Ethnopharmacol. 2011;134(1):50-4. doi: 10.1016/j.jep.2010.11.047.

19. Magos GA, Mateos JC, Páez E, Fernández G, Lobato C, Márquez C, et al. Hypotensive and vasorelaxant effects of the procyanidin fraction from Guazuma ulmifolia bark in normotensive and hypertensive rats. J Ethnopharmacol. 
2008;117(1):58-68. doi: 10.1016/j.jep.2008.01.015.

20. Lahlou S, Tangi KC, Lyoussi B, Morel N. Vascular effects of Tanacetum vulgare L. leaf extract: in vitro pharmacological study. J Ethnopharmacol. 2008;120(1):98-102. doi: 10.1016/j.jep.2008.07.041.

21. Gilani AH, Bashir S, Khan AU. Pharmacological basis for the use of Borago officinalis in gastrointestinal, respiratory and cardiovascular disorders. J Ethnopharmacol. 2007;114(3):393-9. doi: 10.1016/j.jep.2007.08.032.

22. Ameer OZ, Salman IM, Najim HS, Abdullah GZ, Abdulkarim MF, Yam MF, et al. In vitro pharmacodynamic profile of Loranthus ferrugineus: evidence for noncompetitive antagonism of norepinephrine-induced vascular contraction. J Acupunct Meridian Stud. 2010;3(4):272-82. doi: 10.1016/s2005-2901(10)60048-9.

23. Xie YW, Xu HX, Dong H, Fiscus RR, But PP. Role of nitric oxide in the vasorelaxant and hypotensive effects of extracts and purified tannins from Geum japonicum. J Ethnopharmacol. 2007;109(1):128-33. doi: 10.1016/j. jep.2006.07.015.

24. Gondwe M, Kamadyaapa DR, Tufts M, Chuturgoon AA, Musabayane CT. Sclerocarya birrea [(A. Rich.) Hochst.] [Anacardiaceae] stem-bark ethanolic extract (SBE) modulates blood glucose, glomerular filtration rate (GFR) and mean arterial blood pressure (MAP) of STZ-induced diabetic rats. Phytomedicine. 2008;15(9):699-709. doi: 10.1016/j.phymed.2008.02.004.

25. Abreu IC, Marinho AS, Paes AM, Freire SM, Olea RS, Borges $\mathrm{MO}$, et al. Hypotensive and vasorelaxant effects of ethanolic extract from Jatropha gossypiifolia L. in rats. Fitoterapia. 2003;74(7-8):650-7. doi: 10.1016/j.fitote.2003.07.002.

26. Oh KS, Ryu SY, Oh BK, Seo HW, Kim YS, Lee BH. Antihypertensive, vasorelaxant, and antioxidant effect of root bark of Ulmus macrocarpa. Biol Pharm Bull. 2008;31(11):2090-6. doi: 10.1248/bpb.31.2090.

27. Ichimura T, Yamanaka A, Ichiba T, Toyokawa T, Kamada Y, Tamamura T, et al. Antihypertensive effect of an extract of Passiflora edulis rind in spontaneously hypertensive rats. Biosci Biotechnol Biochem. 2006;70(3):718-21. doi: 10.1271/bbb.70.718.

28. Ryu SY, Oh KS, Kim YS, Lee BH. Antihypertensive, vasorelaxant and inotropic effects of an ethanolic extract of the roots of Saururus chinensis. J Ethnopharmacol. 2008;118(2):284-9. doi: 10.1016/j.jep.2008.04.011.

29. Nguelefack-Mbuyo PE, Nguelefack TB, Dongmo AB, Afkir S, Azebaze AG, Dimo T, et al. Anti-hypertensive effects of the methanol/methylene chloride stem bark extract of Mammea africana in l-NAME-induced hypertensive rats. J Ethnopharmacol. 2008;117(3):446-50. doi: 10.1016/j. jep.2008.02.028.

30. Cherkaoui-Tangi K, Lachkar M, Wibo M, Morel N, Gilani AH, Lyoussi B. Pharmacological studies on hypotensive, diuretic and vasodilator activities of chrysin glucoside from Calycotome villosa in rats. Phytother Res. 2008;22(3):35661. doi: 10.1002/ptr.2322.

31. Wongcome T, Panthong A, Jesadanont S, Kanjanapothi D, Taesotikul T, Lertprasertsuke N. Hypotensive effect and toxicology of the extract from Coscinium fenestratum (Gaertn.) Colebr. J Ethnopharmacol. 2007;111(3):468-75. doi: $10.1016 /$ j.jep.2006.12.019.
32. Ghayur MN, Gilani AH. Radish seed extract mediates its cardiovascular inhibitory effects via muscarinic receptor activation. Fundam Clin Pharmacol. 2006;20(1):57-63. doi: 10.1111/j.1472-8206.2005.00382.x.

33. Tao L, Hu HS, Shen XC. Endothelium-dependent vasodilatation effects of the essential oil from Fructus Alpiniae Zerumbet (EOFAZ) on rat thoracic aortic rings in vitro. Phytomedicine. 2013;20(5):387-93. doi: 10.1016/j. phymed.2012.12.014.

34. Kunhachan P, Banchonglikitkul C, Kajsongkram T, Khayungarnnawee A, Leelamanit W. Chemical composition, toxicity and vasodilatation effect of the flowers Extract of Jasminum sambac (L.) Ait. "G. Duke of Tuscany". Evid Based Complement Alternat Med. 2012;2012:471312. doi: $10.1155 / 2012 / 471312$

35. Janbaz KH, Hamid I, Qadir MI. Spasmolytic, bronchodilator and vasodilator activities of aqueous-methanolic extract of Ocimum basilicum. Int J Agric Biol. 2014;16(2):1-9.

36. Pereira SL, Marques AM, Sudo RT, Kaplan MA, ZapataSudo G. Vasodilator activity of the essential oil from aerial parts of Pectis brevipedunculata and its main constituent citral in rat aorta. Molecules. 2013;18(3):3072-85. doi: 10.3390/molecules 18033072 .

37. Janbaz KH, Nisa M, Saqib F, Imran I, Zia-Ul-Haq M, De Feo V. Bronchodilator, vasodilator and spasmolytic activities of methanolic extract of Myrtus communis L. J Physiol Pharmacol. 2013;64(4):479-84.

38. Kang P, Ryu KH, Lee JM, Kim HK, Seol GH. Endotheliumand smooth muscle-dependent vasodilator effects of Citrus aurantium L. var. amara: focus on $\mathrm{Ca}(2+)$ modulation. Biomed Pharmacother. 2016;82:467-71. doi: 10.1016/j. biopha.2016.05.030.

39. Shah AJ, Gilani AH. Aqueous-methanolic extract of sweet flag (Acorus calamus) possesses cardiac depressant and endothelial-derived hyperpolarizing factor-mediated coronary vasodilator effects. J Nat Med. 2012;66(1):119-26. doi: 10.1007/s11418-011-0561-7.

40. Cherkaoui-Tangi K, Israili ZH, Lyoussi B. Vasorelaxant effect of essential oil isolated from Nigella sativa L. seeds in rat aorta: Proposed mechanism. Pak J Pharm Sci. 2016;29(1):1-8.

41. Victório CP, Kuster RM, Moura RS, Lage CL. Vasodilator activity of extracts of field Alpinia purpurata (Vieill) K: Schum and A. zerumbet (Pers.) Burtt et Smith cultured in vitro. Braz J Pharm Sci. 2009;45(3):507-14. doi: 10.1590/ s1984-82502009000300017.

42. Paredes A, Palacios J, Quispe C, Nwokocha CR, Morales G, Kuzmicic J, et al. Hydroalcoholic extract and pure compounds from Senecio nutans Sch. Bip (Compositae) induce vasodilation in rat aorta through endothelium-dependent and independent mechanisms. J Ethnopharmacol. 2016;192:99-107. doi: 10.1016/j. jep.2016.07.008.

43. Dib I, Fauconnier ML, Sindic M, Belmekki F, Assaidi A, Berrabah $\mathrm{M}$, et al. Chemical composition, vasorelaxant, antioxidant and antiplatelet effects of essential oil of Artemisia campestris L. from Oriental Morocco. BMC Complement Altern Med. 2017;17(1):82. doi: 10.1186/ s12906-017-1598-2.

44. Guerrero MF, Puebla P, Carrón R, Martín ML, Arteaga 
L, Román LS. Assessment of the antihypertensive and vasodilator effects of ethanolic extracts of some Colombian medicinal plants. J Ethnopharmacol. 2002;80(1):37-42. doi: 10.1016/s0378-8741(01)00420-2.

45. Sadeghimahalli F, Khaleghzadeh-Ahangar $H$, Baluchnejadmojarad T. Role of prostaglandins in the vasodilator effect of the aqueous extract from Artemisia апnua plant in streptozotocin-induced diabetic rats. Annu Res Rev Biol. 2019;36(1):1-10. doi: 10.9734/arrb/2019/ v31i630069.

46. Tapas AR, Sakarkar DM, Kakde RB. Flavonoids as nutraceuticals: a review. Trop J Pharm Res. 2008;7(3):108999. doi: 10.4314/tjpr.v7i3.14693.

47. Nijveldt RJ, van Nood E, van Hoorn DE, Boelens PG, van Norren K, van Leeuwen PA. Flavonoids: a review of probable mechanisms of action and potential applications. Am J Clin Nutr. 2001;74(4):418-25. doi: 10.1093/ajcn/74.4.418.

48. Ciumărnean L, Milaciu MV, Runcan $\mathrm{O}$, Vesa Ș C, Răchișan AL, Negrean V, et al. The effects of flavonoids in cardiovascular diseases. Molecules. 2020;25(18):4320. doi: $10.3390 /$ molecules 25184320 .

49. Ryan D, Robards K. Phenolic compounds in olives. Analyst. 1998;123(5):31R-44R. doi: 10.1039/a708920a.

50. Carocho M, Ferreira IC. The role of phenolic compounds in the fight against cancer--a review. Anticancer Agents Med Chem. 2013;13(8):1236-58. doi: 10.2174/18715206113139990301.

51. Jiang F, Dusting GJ. Natural phenolic compounds as cardiovascular therapeutics: potential role of their antiinflammatory effects. Curr Vasc Pharmacol. 2003;1(2):135-56. doi: 10.2174/1570161033476736.

52. Duffy SJ, Vita JA. Effects of phenolics on vascular endothelial function. Curr Opin Lipidol. 2003;14(1):21-7. doi: $\quad 10.1097 / 00041433-200302000-00005$.

53. Guimarães AG, Serafini MR, Quintans-Júnior LJ. Terpenes and derivatives as a new perspective for pain treatment: a patent review. Expert Opin Ther Pat. 2014;24(3):243-65. doi: $10.1517 / 13543776.2014 .870154$.

54. Santos MR, Moreira FV, Fraga BP, de Souza DP, Bonjardim LR, Quintans-Junior LJ. Cardiovascular effects of monoterpenes: a review. Rev Bras Farmacogn. 2011;21(4):764-71. doi: 10.1590/s0102$695 \times 2011005000119$.

55. Tariq A, Sadia S, Pan K, Ullah I, Mussarat S, Sun F, et al. A systematic review on ethnomedicines of anti-cancer plants. Phytother Res. 2017;31(2):202-64. doi: 10.1002/ptr.5751.

56. Eseyin OA, Sattar MA, Rathore HA. A review of the pharmacological and biological activities of the aerial parts of Telfairia occidentalis Hook. f. (Cucurbitaceae). Trop J Pharm Res. 2014;13(10):1761-9. doi: 10.4314/tjpr. v13i10.28.

57. Moshi MJ, Otieno DF, Weisheit A. Ethnomedicine of the Kagera region, north western Tanzania. Part 3: plants used in traditional medicine in Kikuku village, Muleba district. J Ethnobiol Ethnomed. 2012;8:14. doi: 10.1186/1746-42698-14.

58. Bhat JA, Kumar M, Bussmann RW. Ecological status and traditional knowledge of medicinal plants in Kedarnath Wildlife Sanctuary of Garhwal Himalaya, India. J Ethnobiol Ethnomed. 2013;9:1. doi: 10.1186/1746-4269-9-1.

59. Altemimi A, Lakhssassi N, Baharlouei A, Watson DG, Lightfoot DA. Phytochemicals: extraction, isolation, and identification of bioactive compounds from plant extracts. Plants (Basel). 2017;6(4):42. doi: 10.3390/plants6040042.

60. Woo CS, Lau JS, El-Nezami H. Herbal medicine: toxicity and recent trends in assessing their potential toxic effects. In: Shyur LF, Lau ASY, eds. Advances in Botanical Research. Vol 62. Academic Press; 2012. p. 365-84. doi: 10.1016/b9780-12-394591-4.00009-x.

61. Bateman J, Chapman RD, Simpson D. Possible toxicity of herbal remedies. Scott Med J. 1998;43(1):7-15. doi: 10.1177/003693309804300104.

62. Mensah ML, Komlaga G, Forkuo AD, Firempong C, Anning AK, Dickson RA. Toxicity and safety implications of herbal medicines used in Africa. In: Herbal Medicine. IntechOpen; 2019. doi: 10.5772/intechopen.72437.

63. Parasuraman S. Toxicological screening. J Pharmacol Pharmacother. 2011;2(2):74-9. doi: 10.4103/0976500x.81895. 